\title{
Islam in Africa, Islam in Globalization
}

On October 15, 2105, the International Institute of Islamic Thought commemorated Ali Mazrui's (1933-2014) first death anniversary by convening a seminar to honor their mutual close and lasting relationship. Mazrui served as the editor-in-chief of the American Journal of Islamic Social Sciences (2009-14), participated in many of the institute's events, and was awarded the IIIT Distinguished Scholar Award in 2011. In addition, he bequeathed his collection of papers and publications to IIIT.

His widow Pauline Utimazrui opened the seminar by recalling how her late husband always spoke the truth regardless of the consequences, how he decided to attend Columbia University because so many African students were going there, and how he sought to bring up controversial issues to force people to think outside the box. She said that he was a very happy and grateful man who appreciated others, liked to live a simple life and be in the moment, and did not believe in accumulating wealth.

Keynote speaker Ebrahim Rasool, former ambassador of South Africa to the United States and a long-time activist who was jailed for his anti-apartheid activities, spoke on "Ali Mazrui: Beacon at the Intersection of Islam and Africa." He described Mazrui as follows:

Standing for justice is the point of the triangle which is least populated, or if it is populated it may well be populated in the absence of understanding the implications of belief in the unity of God or the understanding of the dynamism of knowledge. Professor Ali Mazrui will be remembered for epitomizing the completeness and perfection of this golden triangle [of belief, knowledge and justice], for indeed his knowledge was founded in his unflinching commitment to Tauhid or unity and this, in turn, impelled him towards utilizing his intellect both towards identifying the sources of injustice in the world and positing theoretical and practical solutions towards justice.

He reminded his audience how Mazrui never shied away from controversy, as can be seen in his battle with National Public Radio (NPR) in terms of his production and defense of "The Africans: The Triple Heritage," disagreements with much of post-colonial Africa's ideological or philosophical thinking, and assertion of a distinction between theological Islam and historical Islam. On a more personal level, in 1969 he rejected an invitation extended 
by the University of Cape Town to deliver a public lecture because he could not bring along his white British wife.

After this, Mazrui's colleagues Abubaker al-Shingieti (IIIT), Seifudein Adem (Binghamton University), Sulayman Nyang (Howard University), and Bernadette Paolo (The Africa Society) reflected upon their interactions with him. Nyang told stories about how Mazrui was not apologetic about being an African, that he was comfortable with this identity and with English, that he was very influential in the Middle East, and that he was not afraid to talk with those whom the West did not like. Paolo, after talking about their work together, said that he was "as loyal and kind as he was brilliant ... he was a presence."

Caitlyn Bolton (City University of New York), who presented "Making Africa Legible: Kiswahili Arabic and Orthographic Romanization in Colonial Zanzibar," focused primarily on how Christian missionaries were determined to romanize the modified Arabic script used to write Kiswahili in order to make Zanzibar more "legible" to Europe, thwart Islam's inroads, and monitor their minions' correspondence. The colonial officials, surprisingly, disagreed with this policy and asserted, contrary to the missionaries' claims, that the modified Arabic script was eminently suitable for representing Kiswahili's sounds. However, after independent Tanganyika and Zanzibar united to create Tanzania, romanization won out mainly because it was more practical and utilitarian (necessary to get a job). This was perhaps also due to the 1964 pogroms against the island's Arab elites by the African-majority Zanzibaris and the long-standing Omani slave trade. Moreover, the more populous and largely Christian former Tanganyika had nothing in common with Zanzibari culture and history, and Swahili was already an accepted transnational tribal language.

Youssef Carter (University of California, Berkeley) spoke on "Muhajirrun wal Ansar: Mobilities and Memory among Muslims of African Descent" in the context of the Mustafawiyy Tariqa, a transnational Sufi order instituted in 1966 by Shaykh Mustafa Gueye Haydar in Senegal. A small group of predominantly African-American Muslims founded a community in Moncks Corner, SC. The community, located on a former slave plantation, is close to the port of Charleston, through which approximately 60 percent of all African Muslim slaves passed. Following Ali Mazrui's concept of a "Triple Heritage," Carter discussed how African and African-American Muslims live a "triple consciousness" in terms of being "African elsewhere" and articulate a collective desire to inhabit a Muslim-majority environment, one that is particularly West African (regardless of actual location). Shaykh Arona Faye Al-Faqir, 
who leads this particular community, focuses his students' attention on spiritual purification and righteousness and has become known both in Moncks Corner and nearby states as a man of great generosity who often houses and feeds people in need. One of his main efforts involves helping formerly incarcerated Muslims find jobs. Carter concluded by suggesting that West African Sufism could serve as a possible site of convergence capable of reconciling supposed rifts between an American body politic and Muslim communities situated on American soil.

Naveed Sheikh's (Keele University, UK) presentation, "Can the Subaltern Act? Mazrui on the Error in 'Terror," stated that Mazrui wrote for a broad constituency, saw religion as more important than race, was a skeptical liberal, and considered terrorism a highly politicized term applied to those who "challenge a system that doesn't work for them." Mazrui, an "unapologetic Muslim," remarked that the UN might be fighting terrorism without investigating its causes, which reflects an inability to engage with its context and is one sign of a continued imperial mindset. Mazrui was all about understanding, for "understanding is not to condone." Sheikh refuted the contention that Mazrui made only marginal contributions to the question of political violence and terrorism by stating that he did not regard terrorism as standing alone qua politics or field of study, but rather as being related to and flowing from "the entirety of structural, historical, and cultural forces that have shaped Muslim societies since the advent of imperialism." Therefore, Mazrui's "subaltern approach to terrorism and terrorism studies has to be understood in the context of the larger themes, tropes, and commitments that characterize his paradigmatic treatment of the Third World."

Ahmed Salem (Zayed University, UAE), "Mazrui's Islamic Scholarship: Expanding Horizons, Meeting Challenges," spoke on how Mazrui moved from political science to cultural studies, and from African studies to global studies. In terms of mainstream political science, he was an Africa-first scholar and was far more interested in applied, instead of theoretical, research. He was a comparativist as opposed to only a political scientist, because he also included international relations in his research. Mazrui asserted the primacy of culture over economics and security, saw Islam as an impactful cultural force in Africa vis-à-vis postcolonial politics and also in domestic politics, and always called for employing Islamic values in African, even non-Muslim, contexts. Mazrui also maintained that Islam is an African religion, because there are just as many North African Muslims as there are sub-Saharan Muslims, and that Islam is the best way to resist colonialism. Although he never "detached" himself from Africa, where he was recognized as a towering scholar, he was not welcomed 
in African studies circles because he used Islam to respond to the intellectuals' far-reaching embrace of both Marxism and Afrocentrism.

Rachid Mrani (University of Quebec), who spoke on "Values between Islamic and Western Models: Mazrui's Struggle for a System of Universal Values," remarked that Mazrui considered Islam a set of core values that guide human life and therefore do not threaten either humanistic or western values. Mazrui maintained that both civilizations shared the same values until the onset of modernity and secularism, after which barriers to understanding were raised. He highlighted the danger of stereotypes and binaries, said that there must be a differentiation between provocation and freedom of expression (e.g., Salman Rushdie), and that it is dangerous to make one's values the standard by which to measure others. One essential Islamic value for today, Mazrui believed, was to respect diversity, for "We have created you from male and female and made you peoples and tribes that you may know one another" (Q. 49:13). Throughout his life, Mazrui sought to reconcile the Islamic world and the West by making each one's values, concepts of sacredness, and social realities. He was also interested in how language and culture shape the Muslims' various environments and called for renewing Islamic thought so that it would remain relevant to the Muslims' daily life.

Jay Willoughby

AJISS

Herndon, VA 